\title{
How to Realize the Internationalization of Chinese as a Foreign Language Professional Education
}

\author{
Ying Zhang \\ International School, Zibo Vocational Institute, 255314, China
}

\begin{abstract}
Keywords: Chinese as a foreign language, Professional education, Internationalization, Quality
\end{abstract} education

\begin{abstract}
With the popularity of Chinese in the world, the number of people learning Chinese around the world is on the increase, to promote the development of the internationalization of Chinese professional. Professional education internationalization of Chinese development in view of its own development demand, the internationalization of Chinese language is the inevitable trend of the construction of the acquisition, but also the important ways to solve "Chinese teacher scarcity", it also plays an important role in the development of students' future employment. In this paper, to realize the internationalization of Chinese as a foreign language professional education significance, methods, such as a detailed analysis, so as to realize the internationalization of Chinese as a foreign language is the inevitable choice of Chinese as a foreign language professional construction and development.
\end{abstract}

\section{Introduction}

The internationalization of higher education is an inevitable choice, is also an important symbol of economic globalization background. With the augmentation of the trend of global integration and the rapid development of social economy, increasingly shows the characteristics of diversification and internationalization of higher education. Since reform and opening up in China, the international exchange in growing, the internationalization of Chinese as a foreign language. In order to comply with the party's congress put forward "independent innovation, the construction of new country" the grand goal, will continuously to reform higher education idea, cultivate high comprehensive quality, strong innovation ability, a new type of talents with international vision, as a result, Chinese as a foreign language professional education internationalization is critical.

\section{The theory and realistic meaning for speeding up the internationalization of Chinese as a foreign language professional construction}

The concept of higher education internationalization in different countries on its definition is different. The concept of the first European was raised in 1989; the local education association defines like this: "the internationalization is a development process, in this process, the localization of higher education tendency is less, and heavily toward internationalization situation." This is the current industry more agree with one definition, elements described on the internationalization of higher education have greater definition ${ }^{[1]}$.From different, according to the description on the definition of higher education internationalization can from communication, professional content, organization, etc. Under the trend of internationalization of higher education, and continuously strengthen the professional education internationalization become an important content. Chinese as a foreign language professional has a certain particularity, it is set up under the background of Chinese international promotion, dedicated to Chinese and foreign cultural exchanges between the language class professional talents. From the professional quality, internationalization of higher education will be more meaningful. In addition, the Chinese as a foreign language is a new type of professional, whether in the direction of talent training, objectives, curriculum in different industries have different definition, and professional implementation will face more obstacles ${ }^{[2]}$.

At present, most people have about the Chinese as a foreign language majors have error, often to mix with Chinese teaching Chinese as a foreign language as a whole. But, in fact, major and Chinese 
teaching Chinese as a foreign language is different in concept; there are both connection and difference between the two. Teaching Chinese as a foreign language for students can be directly to teach the Chinese language, teaching Chinese historical and cultural knowledge, in 1950, under the guidance of premier Zhou Enlai, for international students from the Czech republic, Hungary and other countries set up the "eastern Europe specialized training class to exchange students Chinese language and culture", marked the beginning of Chinese as a foreign language professional towards internationalization. Language communication is a social behavior, the degree of a country's economic development and international status, the degree of opening to the outside world, science and technology, military strength and so on will decide to internationalization of Chinese as a foreign language, and communication effect. Our country since reform and opening up, our country in political, military and economic strength are increased, and create a number of "Chinese miracle", by the international attention, plus our country is one of the four ancient civilizations, the long history of Chinese cultural charm's spread in the world is accelerated gradually in ${ }^{[3]}$.

According to related survey, in China the government actively promote, set up abroad has more than 300 "Confucius institute", "Chinese hot" in popular in many countries in the world, and have been among the mammoth spread. Relevant statistics show that the number of people learning Chinese around the world added up to more than 30 million, from the Chinese language life status report predicts that by 2010, the number of global learning Chinese as a foreign language will be increased to about 100 million people, all these data are marked the teaching Chinese as a foreign language in our country there has been a significant development. Chinese as a foreign language major and career there is a big difference between Chinese as a foreign language, Chinese language major is set up based on the "Chinese language and culture", is approved by the department of education for undergraduate programs, formally set up in 1983.At the time, in view of the increase in the number of international students in the school of Chinese, in order to solve the problem of less teachers, education department in Beijing, Shanghai and other regions have set up "teaching Chinese as a foreign language professional," the purpose of the setup is to expedite the development of Chinese as a foreign language. Later, in view of the increasingly frequent exchanges with foreign countries, construction of teaching Chinese as a foreign language in accelerating, many colleges and universities are stepping up construction at home and abroad ", "Chinese as a foreign language professional, open the professional has reached more than 150 colleges and universities. Chinese as a foreign language professional training objectives are also beginning to change, the transition from training teachers to engage in teaching and cultural exchanges, a senior Chinese talent [4].In view of this special Chinese as a foreign language, and promote the internationalization of Chinese as a foreign language professional education development.

First of all, professional education internationalization is the inevitable choice of Chinese as a foreign language professional development. In 1997, the education department has written "professional directory of undergraduate course of common colleges and universities and professional introduction to introduce the file of the Chinese professional training objectives are as follows: specialized in Chinese-English bilingual teaching Chinese as a foreign language more attention, as a key point, the goal is to cultivate professional ability is strong, solid and contrast English with Chinese students, also asked the students to the Chinese and foreign culture, the greatest degree of development potential, high level of Chinese as a foreign language professionals; For Chinese as a foreign language professional talents to enterprises and institutions, schools, cultural management departments, government departments and personnel in charge of foreign affairs language communication, will spread the culture of the two countries, all these need to be students with high international vision and the historical cultural background knowledge. According to the training goal, the internationalization of Chinese as a foreign language professional development will be always internationalization as a development goal.

Second, the internationalization of professional education is set up under the background of international promotion, especially undergraduate specialty construction final selection. Chinese as a foreign language professional will be based on the development of Chinese language teaching, and to improve the Chinese teaching and update, to expand, and the internationalization of Chinese as a 
foreign language professional development as an important goal. In 2005, Beijing successfully hosted the first world Chinese conference, marking the Chinese as a foreign language teaching will be toward the internationalization of Chinese evolution. Chinese conference organizers leadership on the world of Chinese teaching to point out that the work should actively change ideas, will focus on Chinese teaching: the first is the increasing shift in Chinese teaching strategy, from the original internally into international promotion of Chinese as a foreign language; Second is to push forward the strategy of "introducing" [5], constantly will love Chinese foreign talent introduction to the domestic, to speed up the strategy of "going out" at the same time; Increasing popularization ideas from the professional development of teaching Chinese as a popularization, the application of Chinese language teaching; Constantly to perfect promotion mechanism, from the education system to promote to the outside of the education system, and actively to folk at home and abroad; Marketing model transformation, is dominated by the government to market operation; Education method from textbooks taught to make full use of electronic information technology, multimedia technology. On the basis of the above this shift, the leadership of this meeting is proposed to build overseas teachers, accelerate the transformation of Chinese as a foreign language professionals training mode, to promote internationalization of Chinese as a foreign language professional development trend.

Third, improve the internationalization of professional education also must solve some difficult problems, for example, the problem such as "Chinese teachers scarce", this is an important means of Chinese as a foreign language professional students employment. With the emergence of "Chinese hot" wave, the number of Chinese learning in the world already broke through 50 million, but the world really engaged in the foreign language talents were very small, only about 30000, the proportion between teachers and students for the latter, in the case of "shortage of Chinese teachers" in the world. And, as foreign language professional students after graduation unemployment is very high, less employment path selection. The main cause of the problem is: one is the narrow channels of employment, the second is the talent training mode of old, can't meet the demand of the overseas Chinese as a foreign language teacher. To solve these problems, we should accelerate the internationalization of Chinese as a foreign language professional construction process, how to develop domestic and foreign exchange and communication; realize the cooperation in running schools, so as to provide broader jobs for graduates.

\section{The problems of Chinese as a foreign language professional education internationalization existing in the current}

Chinese as a foreign language professional course setting the purpose is to provide service for teaching Chinese as a foreign language. Language as a cultural form, under the background of Chinese internationalization, to promote the development of Chinese language teaching career, cultural transmission has important strategic value. Therefore, we should improve the level of Chinese as a foreign language professional standardization development. In view of the specialty is a new type of Chinese as a foreign language, its development time is the longest do not exceed 20 years of history, and the traditional professional, there are still more non-standard, immature, hinder the internationalization development needs. At present, the problems existing in the internationalization of Chinese as a foreign language professional education mainly reflects in:

First of all, professional goals are not clear, the curriculum is not reasonable, it is difficult to adapt to the internationalization of professional education requirements. Even in our country has the higher school undergraduate course specialty catalog and introduction, have more comprehensive description of Chinese as a foreign language professional goal, due to the nature of school, education level, there are different regional culture and university in the professional construction of the talents training goal of guiding ideology, there are large differences. Many colleges and universities in personnel training mode only emphasize "wide caliber" led to the narrow professional orientation direction, curriculum system construction is not enough comprehensive Chinese as a foreign language; there are more unreasonable places existing in the set of curriculum, it is difficult to adapt to the economic development of globalization and regionalization. 
Secondly, teaching Chinese as a foreign language did not attach enough importance to intercultural communication, cultivate talented person cannot achieve internationalization, foreign language level and the international foreign exchange capacity is weak. Object of teaching Chinese as a foreign language most of them are foreigners, and most of the foreign language learning difficulties and errors come from the native language, therefore, to make teaching could be carried out smoothly, to improve the teaching effect by the foreign language teachers must first to understand students native language system and structure.

Finally, employment channels are smooth enough. At home, college is a place where students daily life, living, the recruitment of teachers in colleges and universities of professional capacity limit is higher, undergraduates have few can enter the work of colleges and universities, which creates a Chinese as a foreign language majors in teaching Chinese as a foreign language is limited in China. Domestic Chinese as a foreign language most of the graduates is no chance to abroad to work in the Chinese as a foreign language, nor in teaching Chinese as a foreign language in China. A lot of Chinese as a foreign language undergraduate students have to find new jobs through one's deceased father grind.

\section{Countermeasures of the problems existing in the internationalization of Chinese as a foreign language professional education}

\section{Clear professional goals, to optimize the curriculum}

Chinese as a foreign language professional to both inside and outside in the curriculum, students are required to have the following several aspects of knowledge: Chinese language knowledge, language knowledge, psychology, pedagogy, Chinese and western cultural knowledge and so on. Between Chinese and western cultural differences on the curriculum, teaching Chinese as a foreign language can not only set Chinese text teaching, must go "Chinese teaching on the basis of open and compatible with integrated road". Strengthening the study of politics, economy, culture, and strengthen the understanding of Chinese and western culture.

\section{The second foreign language courses, improving the ability of communication}

Chinese as a foreign language professional requires students have very high foreign language level and language application ability. Both in teaching and cultural communication, it needs to have very solid language foundation. Therefore, the Chinese as a foreign language professional to set up some more foreign language courses, which will help students to learn a foreign language basic knowledge. At present, most of the Chinese as a foreign language professional foreign language courses are English, and, with the popularity of "Chinese hot", non-native English as a foreign language teachers' demand is gradually increasing. In this context, Chinese as a foreign language professional can also try to learn other languages, such as, French, German, Japanese, etc., can make students broaden employment path. Some of Chinese as a foreign language professional courses can be directly to choice of the original teaching materials, bilingual teaching, such as "selected readings in western linguistics theory", "western culture", "bilingual acquisition", such as comprehensive and systematic in foreign language teaching.

\section{Establish cooperation relationship with famous universities abroad}

The daily spoken English training is seen very seriously by Chinese language learning, is the key to improve the students' Chinese level. Therefore, should actively and build up cooperation with famous universities abroad, can send students to study abroad and the exchange, also can go to the joint mechanism to carry on the practice and study. Exchange students to other countries and the practice to deepen understanding of western culture and improve foreign language ability, communication and development play an important role for the future work.

\section{Conclusion}

In this paper, the necessity of the development of internationalization of Chinese as a foreign language professional education, problems are discussed, and together with the present situation of these problems, puts forward some method to improve the level of Chinese as a foreign language 
professional education, visible, education level of internationalization of Chinese as a foreign language is the inevitable choice of times development, and promote the important embodiment of global economic integration, must continue to improve and perfect teaching method.

\section{References}

[1] Wang Hongbin. Senior - mother tongue education and humanities education professional organic fusion of Chinese as a foreign language professional "ancient Chinese" course orientation and educational reform idea. Journal of Yunnan normal university (Chinese as a foreign language teaching and research),2010,5(4):4-7.

[2] Zhu Chen. Design research of the Chinese as a foreign language professional teaching practice, in Anhui agricultural university, for example. Journal of Anhui agricultural university (social science edition),2011,20(2):134-137.

[3] Wang Zhending. The research and practice for local teachers training mode and curriculum system of Chinese as a foreign language. Journal of research and practice of education and teaching research,2011,25(1):72-76.

[4] Wang Weimin. Theory of culture factors teaching in teaching Chinese as a foreign language - in the fifth "Chinese bridge" Chinese students in China contest, for example. Journal of Anyang normal college,2014(6):112-115.

[5] Yao Jing. Talent training and employment research basing on the regional cooperation of college Chinese as a foreign language professional. Journal of Jixi university: comprehensive version,2012,12(2):5-6. 